\title{
Interval Data Type
}

National Cancer Institute

\section{Source}

National Cancer Institute. Interval Data Type. NCI Thesaurus. Code C95822.

A data type comprised of a set of consecutive values of an ordered base data type. 